\title{
Pulmonary Cryptococcus infections as a manifestation of idiopathic CD4 lymphocytopenia: case report and literature review
}

\author{
Christina S. Thornton ${ }^{1 *}$ D, Oscar Larios ${ }^{2}$, Jennifer Grossman³, Thomas P. Griener ${ }^{4}$ and Steven Vaughan²
}

\begin{abstract}
Background: Idiopathic CD4 lymphocytopenia (ICL) is a rare clinical disease with relative CD4 deficiency in the absence of HIV infection. The pathogenicity of ICL is poorly understood with an unclear incidence rate in the general population. Sequelae of ICL includes AIDS-defining infections, which most commonly includes Cryptococcus neoformans. Typically, C. neoformans infections present with CNS involvement but rarely with extra-CNS manifestations. Here, we present a rare case of ICL with exclusively primary pulmonary cryptococcus and a review of the literature.

Case presentation: A 56-year-old female presented to our tertiary care hospital requiring a right hip open reduction intervention. The patient became febrile during admission, prompting a work-up that included a chest X-ray showing a peripheral pulmonary solitary nodule. Transthoracic biopsy revealed encapsulated yeast forms in keeping with C. neoformans. CD4 counts, repeated at least one month apart, were $<200 \mathrm{cell} / \mathrm{s} / \mathrm{mm}^{3}$, with negative HIV testing. Flow cytometry and genetic testing were completed to elucidate the etiology of the immune deficiency, both of which were unremarkable. She was subsequently treated with 12 months of posaconazole with clinical resolution.

Conclusions: Our patient highlights a rare clinical disease, which a review of literature revealed only five cases in the literature with exclusive pulmonary Cryptococcus in ICL/This case demonstrates the strong clinical acumen required to properly diagnose and ultimately manage the patient.
\end{abstract}

Keywords: Pulmonary cryptococcus, CD4 lymphocytopenia

\section{Background}

Idiopathic CD4 lymphocytopenia (ICL) is a rare clinical disease with relative deficiency of CD4 T-cells in the absence of human immunodeficiency virus (HIV) 1 and 2 infections [1]. It is defined by the US Centers for Disease Control and Prevention (CDC) as a documented absolute CD4 T-lymphocyte count of $<300$ cells $/ \mathrm{mm}^{3}$ or $<$ $20 \%$ of total T-cells on two separate time points at least six weeks apart [2]. Often, ICL is diagnosed in patients with opportunistic infections who test HIV negative.

Cryptococcus neoformans infection is the most common opportunistic infection [1] in ICL patients, however

\footnotetext{
* Correspondence: christina.thornton@ahs.ca

'Division of Respirology, Department of Medicine, University of Calgary, 3330 Hospital Drive NW, Calgary, AB T2N 4N1, Canada

Full list of author information is available at the end of the article
}

typically presents with central nervous system (CNS) manifestations. Here, we present a case of isolated pulmonary cryptococcus infection in a patient with ICL, along with an accompanying review of the literature. We highlight treatment modalities and diagnostic considerations for the clinician when faced with this rare disease.

\section{Case presentation}

A 56-year-old female was admitted to a tertiary care hospital in Calgary, Alberta, Canada for a complex right total hip replacement after a mechanical fall. Her past medical history was significant for insulin dependent type 1 diabetes and a seizure disorder with remote left temporal lobectomy. She was a lifelong non-smoker with an otherwise unremarkable family, social and personal

(c) The Author(s). 2019 Open Access This article is distributed under the terms of the Creative Commons Attribution 4.0 International License (http://creativecommons.org/licenses/by/4.0/), which permits unrestricted use, distribution, and reproduction in any medium, provided you give appropriate credit to the original author(s) and the source, provide a link to the Creative Commons license, and indicate if changes were made. The Creative Commons Public Domain Dedication waiver (http://creativecommons.org/publicdomain/zero/1.0/) applies to the data made available in this article, unless otherwise stated. 
history. Travel history included visits to Vancouver Island, British Columbia.

Following operative intervention, on post-operative day 3 , she was incidentally noted to be febrile at $38.4{ }^{\circ} \mathrm{C}$ and underwent routine investigations. Physical examination showed a healthy individual with unremarkable vital signs, including oxygen saturation on room air of $95 \%$. Chest auscultation was clear. Neurological examination was within normal limits. Laboratory findings included hemoglobin count of $90 \mathrm{~g} / \mathrm{L}$, platelet count of $129 \times 10^{9} / \mathrm{L}$ and white blood cell count $8.4 \times 10^{9} / \mathrm{L}$.

A routine chest radiograph showed a new nodular opacification in the right upper lung that was not present in prior radiographs one year prior (Fig. 1a). Chest computed tomography [3] showed a small noncalcified and non-cavitating pleural-based lesion laterally in the superior segment of the right lower lobe measuring $14 \times 11 \mathrm{~mm}$ (Fig. 1b). Margins were noted to be irregular with solid components. There was no axillary, mediastinal or hilar adenopathy identified. Given the new occurrence of this lesion, the radiology opinion favored peripheral small adenocarcinoma.

The patient underwent an interventional radiology guided transthoracic biopsy, which was complicated with development of small apical pneumothorax and subsequent chest tube insertion. Histological examination revealed multiple round-oval yeast forms admixed in a background of foamy macrophages. Budding yeast forms were not observed. As is typical for Cryptococcus spp., the yeast forms were variably-sized (ranging from 3 to $9 \mu \mathrm{m})$, the yeast cell wall stained positive by Grocott's methenamine silver (GMS) and the large mucinous capsule was highlighted by mucicarmine staining (Fig. 2a-d). Fontana-Masson stain, which can be used to confirm the diagnosis by demonstrating the melanin pigmentation of Cryptococcus, was not performed.
The patient was subsequently seen in infectious diseases clinic. A serum cryptococcal antigen test was positive, with semi-quantitative titre of 1:40 (Cryptococcal Antigen Lateral Flow Assay, IMMY, Norman, Oklahoma). This assay is reported to detect both $C$. neoformans and C. gattii and has a high sensitivity in immunocompetent and immunocompromised individuals [4]. Further molecular sequencing was not available on the sample. She was started on fluconazole $400 \mathrm{mg}$ oral daily. After initiation, she developed a severe headache and underwent lumbar puncture to rule out unmasking immune reconstitution syndrome from CNS cryptococcosis. Cerebrospinal fluid was negative for cryptococcal antigen and fungal culture. Due to the persistence of headache and a drug interaction with an anti-epileptic medication (carbamazepine) she was subsequently changed to posaconazole $300 \mathrm{mg}$ oral daily. Cryptococcal antigen titres were followed in the year following initiation of posaconazole and decreased to negative levels at the end of treatment.

At time of diagnosis, a CD4 count was noted to be low at $0.286 \times 10^{\wedge 9} / \mathrm{L}\left(0.499-1.651 \times 10^{\wedge^{9}} / \mathrm{L}\right)$ with repeat four months later at $0.334 \times 10^{\wedge} / \mathrm{L}$. HIV testing with 4th Gen ELISA and HIV viral load were negative. An immunologic testing panel done 18 months after initial diagnosis showed normal total numbers of B-cells. Her total T-cell number was decreased at $0.33 \times 10^{\wedge^{9}} / \mathrm{L}$ $\left(0.780-3.00 \times 10^{\wedge} / \mathrm{L}\right)$ with a CD4 count of $0.24 \times 10^{\wedge 9} / \mathrm{L}$ $\left(0.500-2.00 \times 10^{\wedge} / \mathrm{L}\right)$ and CD8 count of $0.07 \times 10^{\wedge} / \mathrm{L}$ $\left(0.200-1.200 \times 10^{\wedge} / \mathrm{L}\right)$. Neutrophil and NK cell counts were within normal limits. This was felt to be supportive of the diagnosis of idiopathic CD4 lymphocytopenia. DNA was tested for over 274 genes known to be associated with immune defects (Blueprint Genetics) and no mutations were found.

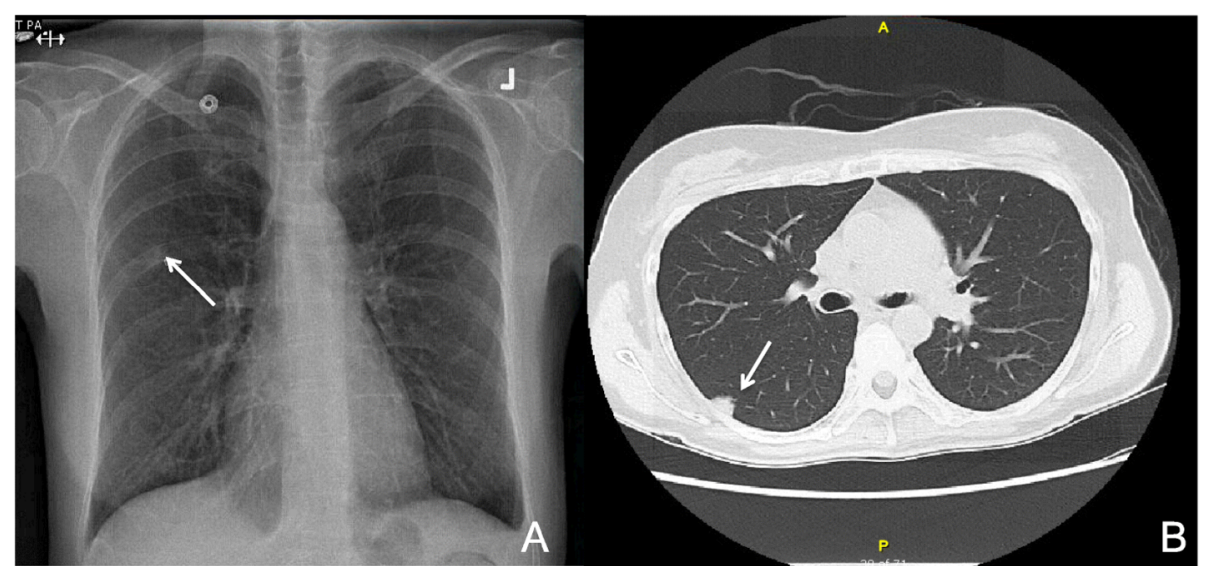

Fig. 1 Chest radiograph demonstrating nodular opacification in the right upper lung (a). Chest computed tomography [3] scan demonstrating non-calcified and non-cavitating pleural-based lesion laterally in the superior segment of the right lower lobe measuring $14 \times 11 \mathrm{~mm}(\mathbf{b})$ 


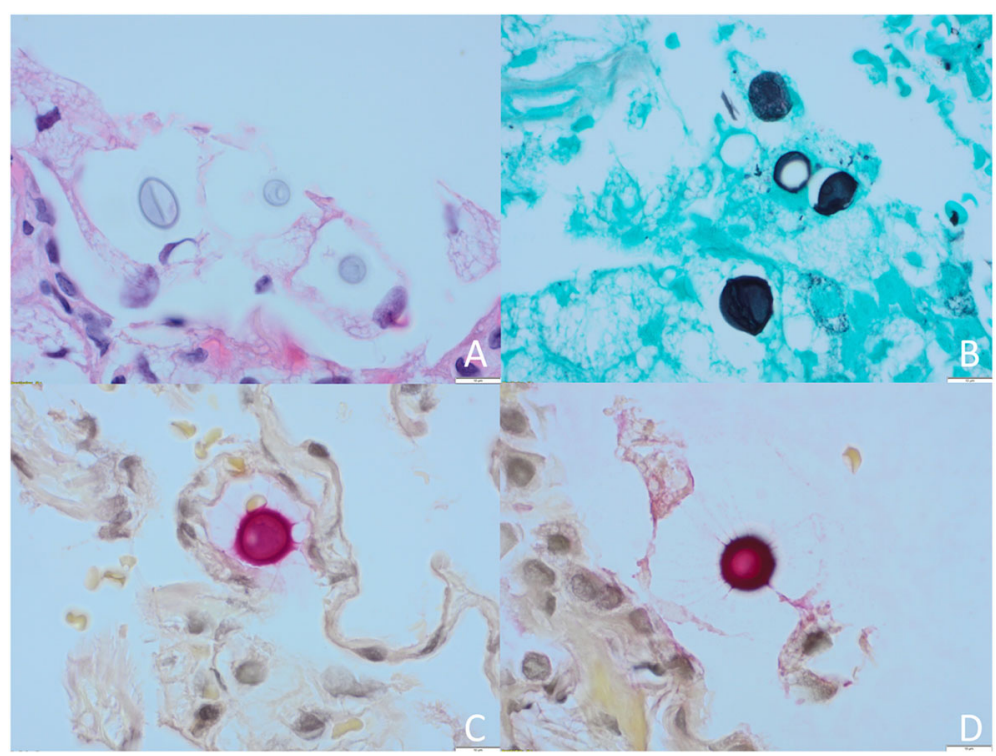

Fig. 2 Pathologic examination of haematoxylin and eosin (H\&E) stained lung tissue, revealing encapsulated and variably-sized oval yeast forms in a background of foamy histiocytes $(\mathbf{a}, 40 \mathrm{x})$. Yeast morphology consistent with Cryptococcus spp. as the yeast cell wall stained positive by Grocott's methenamine silver (GMS) stain (b, 50x) and large capsule positive by mucicarmine stain (c, $\mathbf{d}, 100 x)$

The patient ultimately completed 12 months of posaconazole monotherapy with excellent response. Repeat CT chest imaging done following completion of therapy showed the peripheral predominant ground-glass nodule within the superior segment of the right lower lobe as smaller and less dense when compared to prior measuring $12 \times 8$ compared to $14 \times 11 \mathrm{~mm}$. No further recurrence of Cryptococcus has occurred to date.

\section{Discussion and Conclusions}

ICL is an exceedingly rare disease with unknown incidence in the general population. A review found that
CD4 counts of ICL patients on initial diagnosis were $<$ 150 cells $/ \mathrm{mm}^{3}$ [5]. In contrast, AIDS is defined as an outcome of chronic HIV infection with CD4 count $<200$ cells $/ \mu \mathrm{L}$ or the presence of AIDS-defining conditions regardless of CD4 count. These include infections such as disseminated or extrapulmonary coccidioidomycosis, extrapulmonary cryptococcosis, disseminated mycobacterium and Pneumocystis jiroveci pneumonia [6]. In a review of 23,179 cases within the CDC immunodeficiency registry, 47 met criteria for ICL [7]. There was no reportable association with age (mean age 43 years, range from 17 to 78 years) or gender (male to female ratio of 29:18)

Table 1 Summary of Literature Cases with ICL and Primary Pulmonary Manifestations

\begin{tabular}{|c|c|c|c|c|c|c|}
\hline Reference & Year & Gender & Age & Clinical History & Treatment & Outcome \\
\hline Ahn, et al [22]. & 2005 & Male & 73 & Non-small cell lung cancer & $\begin{array}{l}\text { Amphotericin B }(0.5 \mathrm{mg} / \mathrm{kg} / \text { day }) \\
\text { for } 15 \text { days then switched to } \\
\text { fluconazole } 400 \mathrm{mg} / \text { day }\end{array}$ & $\begin{array}{l}\text { Continued on fluconazole } \\
\text { until lung nodules } \\
\text { disappeared }\end{array}$ \\
\hline Lin, et al [23]. & 1994 & Female & 33 & $\begin{array}{l}\text { Pure red cell aplasia } \\
\text { and human parvovirus } \\
\text { B19 infection }\end{array}$ & $\begin{array}{l}\text { Brief course of amphotericin } \\
\text { B followed by oral fluconazole. }\end{array}$ & $\begin{array}{l}\text { Recurrent anemia requiring } \\
\text { intravenous immunoglobulin } \\
\text { for refractory anemia }\end{array}$ \\
\hline McNulty, et al [24]. & 1991 & Male & 35 & N/A & $\mathrm{N} / \mathrm{A}$ & $\mathrm{N} / \mathrm{A}$ \\
\hline Zaharatos, et al [25]. & 2001 & Male & 47 & $\begin{array}{l}\text { Coinfection with Mycobacterium } \\
\text { tuberculosis }\end{array}$ & N/A & $\begin{array}{l}\text { Comment on } 24 \text { weeks total } \\
\text { of therapy }\end{array}$ \\
\hline Yuanjie, et al [26]. & 2008 & Female & 41 & $\mathrm{~N} / \mathrm{A}$ & $\begin{array}{l}\text { Lobectomy; amphotericin B } 25 \text { mg } \\
\text { /day for } 1 \text { month; amphotericin } \\
\text { B } 25 \text { mg/day plus 5-flucytosine } \\
3 \text { g /day for } 6 \text { weeks; amphotericin } \\
\text { B } 25 \text { mg/day plus 5-flucytosine } \\
3 \text { g/day for } 6 \text { weeks; amphotericin } \\
\text { B } 25 \text { mg/day plus 5-flucytosine } \\
3 \text { g/day for } 12 \text { weeks and fluconazole } \\
150 \text { mg/day as maintenance }\end{array}$ & $\begin{array}{l}\text { Total of four relapses, } \\
\text { maintained on } \\
\text { oral fluconazole. }\end{array}$ \\
\hline
\end{tabular}


amongst ICL patients. Currently, the etiology of ICL is unknown but has been speculated to range from a pathogenic process resulting in subsequent CD4+ apoptosis [8], T-cell kinase dysregulation [9] and mutations in the RAG GTPase pathway [10]. An unidentified genetic mechanism has also been suggested as there have been several reports with familial association $[11,12]$.

Opportunistic pathogens observed in ICL are similar to those in AIDS, however with differing frequencies. A review of $258 \mathrm{ICL}$ patients found the most common to be Cryptococcus (26.6\%), followed by mycobacterial (17.0\%) and PJP (7.7\%) [5]. In comparison, AIDS patients are most frequently infected with cytomegalovirus (33\%) and PJP (29.9\%), with only $2.6 \%$ cryptococcal infections $[13,14]$. From a clinical perspective, the differences between the two diseases are relevant as ICL patients tend to have a progressive decline in $\mathrm{CD} 4$ counts, whereas AIDS patients exhibit a slower decline (or increase if antiretroviral medication is initiated) $[8,15]$.

As mentioned, Cryptococcus neoformans is the most common opportunistic infection amongst ICL patients. There have been reports of cryptococcal osteomyelitis, dermatological manifestation and musculoskeletal involvement [16-19]. Despite this, the vast majority of ICL patients with cryptococcal infections present with primarily CNS involvement. In a prospective American series of 39 patients, one-third of patients were diagnosed with cryptococcal meningitis [8]. A French group also found similar results in $15 \%$ of ICL patients [20]. While less common, reports of cryptococcal encephalitis have also been described [21].

Isolated pulmonary cryptococcosis without CNS involvement is rare with only, to our knowledge using a PRISMA review checklist, five cases in the literature reported (Table 1). Notably, treatment regiments were diverse within the cases. There is currently no gold standard for treatment of pulmonary Cryptococcus in ICL. Often, fluconazole is adequate treatment but the duration of therapy is unclear and should be tailored to the individual patient with severity of illness as guidance [22]. Guidelines for non-meningeal cryptococcal pulmonary infections published by the Infectious Diseases Society of America (IDSA) recommend for mild to moderate disease, administration of fluconazole $400 \mathrm{mg}$ daily for 6-12 months with escalation to CNS therapy for severe disease [3]. Notably, persistently positive serum cryptococcal antigen titers are not criteria for continuous use of therapy. Given the limited cases available for pulmonary Cryptococcus in ICL, we suggest adoption of the IDSA guidelines as a framework for the clinician in treatment of these patients, as was done in our case.

It is noted in the IDSA guidelines that in nonimmunocompromised patients with pulmonary cryptococcosis, to consider a lumbar puncture to rule out asymptomatic CNS involvement. However, for normal hosts with asymptomatic pulmonary nodule or infiltrate, no CNS symptoms, and negative or very low serum cryptococcal antigen, a lumbar puncture can be avoided (B-II). It is unclear where patients with ICL fall into this spectrum. Given the high prevalence of CNS involvement in ICL patients, we would suggest the clinician strongly consider a lumbar puncture to rule out asymptomatic disease in all patients with extra-CNS cryptococcal infection.

Limitations of this study include the lack of sequencing or other molecular tests, highlighting an area of future work that may improve diagnostic utility in this rare disease.

\section{Abbreviations}

AIDS: Acquired immunodeficiency syndrome; CD4: Cluster of differentiation 4; CNS: Central nervous system; CT: Chest computed tomography;

GMS: Grocott's methenamine silver; H\&E: haematoxylin and eosin stain; HIV: Human immunodeficiency virus; ICL: Idiopathic CD4 lymphocytopenia; IDSA: Infectious Diseases Society of America; Ol: Opportunistic infection; PJP: Pneumocystis jiroveci pneumonia

\section{Acknowledgements}

We thank the patient in this manuscript for granting permission to share this case.

\section{Authors' contributions}

CST and SV conceptualized and designed case report with manuscript preparation. TPG obtained pathology data and figure preparation. CST, OL, JG and SV were involved in the patient's care. All authors read and approved the final manuscript.

\section{Funding}

Not applicable.

Availability of data and materials Not applicable.

Ethics approval and consent to participate

Ethics approval is not applicable, consent to participate was provided by the patient.

\section{Consent for publication}

Written consent for publication was obtained from the patient and is available for review upon request.

\section{Competing interests}

The authors declare that they have no competing interests.

\section{Author details}

'Division of Respirology, Department of Medicine, University of Calgary, 3330 Hospital Drive NW, Calgary, AB T2N 4N1, Canada. ㄹivision of Infectious

Diseases, Department of Medicine, University of Calgary, Calgary, AB, Canada. ${ }^{3}$ Division of Hematology and Hematological Malignancies, Department of Medicine, University of Calgary, Calgary, Alberta, Canada. ${ }^{4}$ Department of Pathology \& Laboratory Medicine, Cumming School of Medicine,

Department of Medicine, University of Calgary, Calgary, Alberta, Canada.

Received: 28 May 2019 Accepted: 10 September 2019

Published online: 17 October 2019

\section{References}

1. Yarmohammadi H, Cunningham-Rundles C. Idiopathic CD4 lymphocytopenia: Pathogenesis, etiologies, clinical presentations and treatment strategies. Ann Allergy Asthma Immunol. 2017;119(4):374-8.

2. Centers for Disease C. Unexplained CD4+ T-lymphocyte depletion in persons without evident HIV infection--United States. MMWR Morb Mortal Wkly Rep. 1992;41(30):541-5. 
3. Perfect JR, Dismukes WE, Dromer F, Goldman DL, Graybill JR, Hamill RJ, Harrison TS, Larsen RA, Lortholary O, Nguyen MH, et al. Clinical practice guidelines for the management of cryptococcal disease: 2010 update by the infectious diseases society of america. Clin Infect Dis. 2010:50(3):291-322.

4. McMullan BJ, Halliday C, Sorrell TC, Judd D, Sleiman S, Marriott D, Olma T, Chen SC. Clinical utility of the cryptococcal antigen lateral flow assay in a diagnostic mycology laboratory. PLoS One. 2012;7(11):e49541.

5. Ahmad DS, Esmadi M, Steinmann WC. Idiopathic CD4 Lymphocytopenia: Spectrum of opportunistic infections, malignancies, and autoimmune diseases. Avicenna J Med. 2013:3(2):37-47.

6. Schneider E, Whitmore S, Glynn KM, Dominguez K, Mitsch A, McKenna MT Centers for Disease C, Prevention. Revised surveillance case definitions for HIV infection among adults, adolescents, and children aged $<18$ months and for HIV infection and AIDS among children aged 18 months to $<13$ years--United States, 2008. MMWR Recomm Rep. 2008;57(RR-10):1-12.

7. Smith DK, Neal JJ, Holmberg SD. Unexplained opportunistic infections and CD4+ T-lymphocytopenia without HIV infection. An investigation of cases in the United States. The centers for disease control idiopathic CD4+ Tlymphocytopenia task force. N Engl J Med. 1993;328(6):373-9.

8. Zonios DI, Falloon J, Bennett JE, Shaw PA, Chaitt D, Baseler MW Adelsberger JW, Metcalf JA, Polis MA, Kovacs SB, et al. Idiopathic CD4+ lymphocytopenia: natural history and prognostic factors. Blood. 2008;112(2): 287-94

9. Nehme NT, Schmid JP, Debeurme F, Andre-Schmutz I, Lim A, Nitschke P, Rieux-Laucat F, Lutz P, Picard C, Mahlaoui N, et al. MST1 mutations in autosomal recessive primary immunodeficiency characterized by defective naive T-cell survival. Blood. 2012;119(15):3458-68.

10. Kuijpers TW, ljspeert $H$, van Leeuwen EM, Jansen MH, Hazenberg MD, Weijer KC, van Lier RA, van der Burg M. Idiopathic CD4+ T lymphopenia without autoimmunity or granulomatous disease in the slipstream of RAG mutations. Blood. 2011;117(22):5892-6.

11. Lin SJ, Chao HC, Yan DC, Kuo ML. Idiopathic CD4+ T lymphocytopenia in two siblings. Pediatr Hematol Oncol. 2001;18(2):153-6.

12. Freier S, Kerem E, Dranitzki Z, Schlesinger M, Rabinowitz R, Brautbar C, Ashkirat M, Naparstek Y. Hereditary CD4+ T lymphocytopenia. Arch Dis Child. 1998:78(4):371-2.

13. Buchacz K, Baker RK, Palella FJ Jr, Chmiel JS, Lichtenstein KA, Novak RM, Wood KC, Brooks JT, Investigators H. AIDS-defining opportunistic illnesses in US patients, 1994-2007: a cohort study. AIDS. 2010;24(10):1549-59.

14. Sone K, Muramatsu H, Nakao M, Kagawa Y, Kurokawa R, Sato H, Niimi A. Pneumocystis pneumonia secondary to idiopathic CD4+ Tlymphocytopenia: a comparison of AIDS and non-AIDS patients. Intern Med. 2018;57(3):383-6.

15. Said S, Alkhateeb H, Cooper CJ, Rodriguez E, Trien R, Hernandez GT, Salameh HS. Idiopathic CD4+ lymphocytopenia in Hispanic male: case report and literature review. Int Med Case Rep J. 2014;7:117-20.

16. Menon BS, Shuaib IL, Zamari M, Haq JA, Aiyar S, Noh LM. Idiopathic CD4+ T-lymphocytopenia in a child with disseminated cryptococcosis. Ann Trop Paediatr. 1998;18(1):45-8

17. Zonios DI, Falloon J, Huang CY, Chaitt D, Bennett JE. Cryptococcosis and idiopathic CD4 lymphocytopenia. Medicine (Baltimore). 2007:86(2):78-92

18. Kumlin U, Elmqvist LG, Granlund M, Olsen B, Tarnvik A. CD4 lymphopenia in a patient with cryptococcal osteomyelitis. Scand J Infect Dis. 1997;29(2):205-6.

19. Zanelli G, Sansoni A, Ricciardi B, Ciacci C, Cellesi C. Muscular-skeletal cryptococcosis in a patient with idiopathic CD4+ lymphopenia. Mycopathologia. 2001;149(3):137-9.

20. Regent A, Autran B, Carcelain G, Cheynier R, Terrier B, Charmeteau-De Muylder B, Krivitzky A, Oksenhendler E, Costedoat-Chalumeau N, Hubert P. et al. Idiopathic CD4 lymphocytopenia: clinical and immunologic characteristics and follow-up of 40 patients. Medicine (Baltimore). 2014;93(2): $61-72$.

21. Nunez MJ, de Lis JM, Rodriguez JR, Allegue MJ, Viladrich A, Conde C, Santiago MP, Amigo MC. disseminated encephalic cryptococcosis as a form of presentation of idiopathic T-CD4 lymphocytopenia. Rev Neurol. 1999; 28(4):390-3.

22. Ahn IS, Kim HG, Ryu JS, Kim L, Kwak SM, Lee HL, Yoon YH, Cho JH. A case of pulmonary cryptococcosis with non-small cell lung cancer in idiopathic CD4+ T-lymphocytopenia. Yonsei Med J. 2005;46(1):173-6.

23. Lin JC, Tripathi HM. Pure red cell aplasia and idiopathic CD4 Tlymphocytopenia. Clin Infect Dis. 1994;18(4):651-2.
24. McNulty A, Kaldor JM, McDonald AM, Baumgart K, Cooper DA. Acquired immunodeficiency without evidence of HIV infection: national retrospective survey. BMJ. 1994;308(6932):825-6.

25. Zaharatos GJ, Behr MA, Libman MD. Profound T-lymphocytopenia and cryptococcemia in a human immunodeficiency virus-seronegative patient with disseminated tuberculosis. Clin Infect Dis. 2001;33(11):E125-8.

26. Yuanjie Z, Julin G, Fubing C, Jianghan C. Recurrent pulmonary cryptococcosis in a patient with idiopathic CD4 lymphocytopenia. Med Mycol. 2008;46(7):729-34.

\section{Publisher's Note}

Springer Nature remains neutral with regard to jurisdictional claims in published maps and institutional affiliations.
Ready to submit your research? Choose BMC and benefit from:

- fast, convenient online submission

- thorough peer review by experienced researchers in your field

- rapid publication on acceptance

- support for research data, including large and complex data types

- gold Open Access which fosters wider collaboration and increased citations

- maximum visibility for your research: over $100 \mathrm{M}$ website views per year

At BMC, research is always in progress.

Learn more biomedcentral.com/submissions 